\title{
A TRIPARTITE THEORY OF LOVE
}

\author{
Sam Shpall
}

$(1)$

NE PSYCHOLOGICAL CONDITION has an especially deep connection to the felt meaningfulness of life. The purpose of this essay is to explore the nature of this condition, which I think it is appropriate to call love.

I begin by more precisely articulating my motivating platitude about love and meaning. Having identified this crucial and underappreciated element of love's psychological profile, I use it to select a varied set of examples that it natural to think of as paradigms. I observe that almost all prominent philosophical accounts of love are, surprisingly, silent about some of these paradigm cases. The aim is not to show that these theories are misguided, but to suggest that my approach is distinctive and worth exploring.

I then offer a tripartite theory of love's character. Love is devotion that renders vulnerable and expresses liking. ${ }^{1}$ The theory is in part a response to the current state of philosophical perplexity about love, where controversy abounds concerning even the most basic questions. ${ }^{2}$ One ambition is to provide the requisite psychological detail to make classic debates about love more tractable. For example, the theory may shed new light on questions about whether love is an emotion, whether love is under our control, whether love for various kinds of nonhuman and nonliving objects is possible, and whether love is rationally assessable. Another ambition is to identify important choices we confront in

1 Concerning devotion, the most obvious precursor is Frankfurt, The Reasons of Love. On vulnerability, the most ambitious and interesting discussion is Velleman, "Love as a Moral Emotion." Regarding liking, I am influenced by the treatment of friendship in Nehamas, On Friendship. I trace many more threads of inspiration in what follows.

2 Philosophers disagree about whether love is an emotion (Velleman, "Love as a Moral Emotion"; Brogaard, On Romantic Love), a structure of will (Frankfurt, "On Caring," "Autonomy, Necessity, and Love," and The Reasons of Love), a form of valuing (Kolodny, "Love as Valuing a Relationship"), or a special mode of perception (Jollimore, Love's Vision). They also disagree about how to approach the topic: for example, they disagree about what count as paradigm cases. For a discussion of some of the methodological problems to which this essay responds, see Soble, The Philosophy of Sex and Love, e.g., 129. 
thinking systematically about love, choices that are sometimes obscured in the vast literature on the topic.

\section{THE EXPERIENCE OF MEANING}

Here is my motivating thought. More than anything else, love makes human lives seem meaningful to those who live them. It is the most robustly meaning-generating psychological condition with which we are familiar. ${ }^{3}$

I cannot offer a developed account of the perception or experience of meaning. Few philosophers of love have such accounts. ${ }^{4}$ Yet all of us are familiar with the experience of finding special meaning in, say, a friend's unexpectedly sensitive gesture. For my purposes, it will suffice to make two simple observations that help to distinguish the experience of meaning from experiences with which it might be confused.

First, the experience of meaning is not the same as the perception of objective value. You can find something to be intensely meaningful that you know to be relatively unimportant from the point of view of the universe: consider an old and admittedly over-treasured shirt that you would be devastated to lose, or a much-appreciated visit from a relative who could be spending more time on his medical research. And you can find little or no meaning in something you know to be objectively important: consider an affectless effective altruist, who recognizes the value of her donations even though they do not make a dent in her boundless ennui. ${ }^{5}$

Second, the experience of meaning is not identical to the more common and often trivial experience of desire-satisfaction. (Alternative formulation: it is not the case that all pro-attitudes play the robust meaning-generating role common sense assigns to love.) I am thirsty. When I take a drink in a moment I will not find it particularly meaningful, or meaningful at all. I want to control my back

3 This does not make meaning-generation a necessary condition for love. (Suppose intention is the most behavior-producing psychological condition. It does not follow that behavior-production in any given case is necessary for a state to be an intention.) I am hesitant to endorse the necessity claim about love and meaning, though it may well be true. The robustness claim is a sufficiently useful point of departure.

4 But see Susan Wolf's stimulating reflections in Meaning in Life and Why It Matters.

5 For a profoundly distressing example that resembles this, see Rae Langton's brilliant discussion of Maria von Herbert, who finds no meaning in her moral uprightness ("Duty and Desolation"). A similar case is that of J.S. Mill's depression. His narration of this period includes the following wise conjecture: "If I had loved any one sufficiently to make confiding my griefs a necessity, I should not have been in the condition I was" (Autobiography of John Stuart Mill, 95). 
pain. I take some aspirin and it helps. I value this outcome, but to speak of finding meaning in it sounds forced—indeed, the pain may simply slip away without my noticing. Sally intends to go to work each day, and desires to keep her job, but only for its instrumental benefits. The fact that she does not find it meaningful is exactly why we counsel her to consider a change of career. Ahmed is strongly motivated to pursue casual sex, but he readily acknowledges that he does not find much meaning in it. This explains his simultaneous search for a different kind of intimate relationship.

I cannot make the distinctions between judging things to be valuable, getting things we desire, and finding things meaningful totally precise. I can maintain, however, that the perception of meaning is distinctive, and central to human flourishing. It is largely because we find meaning in life that we continue to live it in the face of hardship. The psychological and moral importance of love is in part explained by its robust connection to this experience of meaning. ${ }^{6}$

One goal of this essay is to develop an account of love that delineates the composition of such a meaning-generating condition. My approach is a broadly functionalist one. I attempt to understand love better by understanding more about this special psychological role. The methodology contrasts with a prevailing (if usually unstated) assumption that analysis of love should begin with paradigm cases, chosen because they exemplify a privileged kind of love object or relationship. I begin with my own set of paradigm cases, selected not for uniformity of object or relationship type, but for exemplification of the meaning-generating role. My cases are chosen to stress the wide variety of sources of meaning in life, and to focus attention on forms of love that I think are obviously interesting but are more frequently discussed by historical than contemporary philosophers.

This methodological point is central. Here is another way of expressing it. There are several fundamental clashes of intuition in sophisticated thinking about love. One such clash concerns which cases are paradigms of the phenomenon. This is a consequential disagreement, since the selection of paradigms determines the contours of our theories. Many thoughtful writers take it to be obvious that the paradigms of love are to be identified on the basis of object kind

6 For some versions of my motivating thought about love and meaning, see Singer, "From The Nature of Love," and Ferracioli, “The State's Duty to Ensure Children Are Loved," 8. Having already registered my debt to Wolf (Meaning in Life and Why It Matters), I will mention my worry that her conception of meaning, as the intersection of objective value and subjective attraction, is unstable. I cannot defend that claim here. But it is worth emphasizing that we can find things meaningful in ways that do not line up with our considered judgments about value. The observation frames a big question for moral philosophy: To what degree should our loving accord with our value judgments? 
(e.g., person) or relationship type (e.g., romantic partnership). But the more uniformity our treatments exhibit, the more we should worry about what we are missing. ${ }^{7}$

Having said this, I should make a clarifying note about my aspirations. I am uninterested in policing use of an English term. I am also uninterested in taking an unnecessarily adversarial stance toward the work that has stimulated my interest in these topics. The view of love articulated here is more capacious than the views given by prominent philosophers, but this does not mean that our accounts are incompatible. It is perfectly legitimate for different thinkers to have different theoretical ambitions. I only ask the reader to consider whether it may be generally unfortunate that the literature on love is intensely focused on a relatively homogeneous set of examples.

\section{PARADIGMS}

I now present five cases that give voice to commonsense judgments about the variety of love, and that exemplify the meaning-generating truism that is my point of departure. There are two main purposes to this presentation. I aim, first, to ground the theoretical reflections to come in ordinary, recognizable phenomena. My tripartite theory will unify these examples, and others like them, by articulating the fundamental underlying similarities between their protagonists in more precise detail. Second, the discussion sets up my observations in the next section about the state of the contemporary philosophical literature, which concern the ways in which prominent accounts of love must ignore at least some of what I and many others regard as paradigm cases. In particular, I will highlight the common convention of tailoring philosophical accounts of love to the special case of love for persons, or to special cases of that special case.

My cases thus offer an alternative to some widespread trends of example choice that are perhaps less than fully imaginative, and that enshrine controversial intuitions. ${ }^{8}$ I try to describe them in a neutral way that does not presuppose

7 I will be particularly interested to contrast my approach with the common (exclusive) interest in love for persons. Even those who worry about this general orientation (Smuts, "Normative Reasons for Love, Parts I and II," 509), or pitch a functionalist story (Jenkins, "Modal Monogamy," 356), rarely develop such thoughts in any detail. But I will also eschew other commonplace assumptions-e.g., about monogamy (Nozick, "Love's Bond") or the necessity of relationships (Kolodny, "Love as Valuing a Relationship").

8 Some writers express sympathy with my general orientation without exploring its consequences in the same sort of detail. They include Frankfurt, The Reasons of Love; Nehamas, Only a Promise of Happiness; and Wolf, The Variety of Values. Plato and Freud are interesting comparisons, as I note below. 
my interpretation of them as paradigms of love. Of course, I invite readers to think of them in this way, and will later help myself to the description. But what matters most is that the examples motivate the coherence and interest of a unified analysis of their protagonists' psychological conditions. If I can convince readers that this analysis is worthwhile and that it has rarely been undertaken, then my main preliminary goals will have been accomplished. I present the cases without interruption before offering further commentary.

World's Best Mom: Max's mom Sherry raised him right. Though there were some turbulent moments between them, especially as they traversed his adolescence, Max recognizes that Sherry consistently acted with compassion, grace, foresight, and great affection. And quite apart from the filial debt he feels, Max also genuinely appreciates Sherry's personality, and enjoys spending time with her. He revels in her successes, helps her when she is in need, and worries about her comfort and happiness as she ages. He does these things not just because he wants to respect what she's done for him, and not just because he enjoys her company and personality, but also because he values her flourishing for its own sake.

Talk to Her: After decades of disappointing searches for a soul mate Nancy decides to embark on motherhood alone. She gives birth to a baby girl she names Alicia, and has never felt so attached to another being or so arrested by the immediacy and depth of her joy. Nancy knows that she would make great sacrifices for Alicia. She is prepared to continue dedicating her life to this fragile creature. However, Nancy's doctors soon discover that Alicia has an untreatable degenerative disease, which will render her brain function catastrophically impaired and take her life within a few years. Nancy is crushed by this revelation. Still, she commits to Alicia with renewed vigor, and spends the happiest times of her life as her doomed daughter's caretaker, never wavering in her displays of largely unreciprocated affection. ${ }^{9}$

Man's Best Friend: Kevin's seeing-eye dog Orson is a wonderful companion. But he has a streak of emotional volatility, and gets depressed when deprived of his nightly pampering. While it sometimes interferes with his other relationships, Kevin is completely dedicated to Orson, and never misses an opportunity to do right by his bud. Kevin's friends and

9 For discussions of Pedro Almodovar's greatest film, from which some features of the example are drawn, see Eaton, Talk to Her, and Shpall, "The Men of Talk to Her." For an insightful discussion of love for infant children, see Kennett, "True and Proper Selves." 
family sometimes chastise him for what they see as a misguided loyalty, which often deprives them of his pleasant company. Kevin listens to their complaints respectfully but remains committed to his way of life. After all, he thinks, Orson is a joyous, innocent creature, whose affectionate help makes it much easier to navigate the world. And he fills Kevin's life with a unique sort of companionate satisfaction that personal relationships, with their inevitable strains and complications, have never really afforded him. ${ }^{10}$

The Book: After years of illness, and inner turmoil about the value of his dandified existence, Marcel decides to give up his engagement in the life of upper-crust Parisian society in order to devote himself to the composition of a massive literary work. Marcel is resolute in executing this decision. He sequesters himself at home and spends his remaining years pursuing his grand artistic project. ${ }^{11} \mathrm{He}$ has an ecstatic conception of the activity of writing and of his book's value. Indeed, Marcel sees the aesthetic achievements of literary composition as his only chance at a happy and meaningful life. ${ }^{12}$

The Way of Perfection: Teresa grows up in a pious household, and at an early age is captivated by stories about the lives of the saints. When her mother dies the young girl undergoes a transformative period of grief. Convinced that worldly concerns are futile, she takes up residence in a monastery. Teresa devotes her life to the perfection of divine worship,

"My dogs are my friends and part of my family. I know them better, actually, than I know the man living across the street. I do what I can to care for them and to keep us safe and well. They share more of my life than do my human friends" (Safina, Beyond Words, 287).

"So far from going into society, I would not even permit people to come and see me at home during my hours of work, for the duty of writing my book took precedence now over that of being polite or even kind.... I should have the courage to reply to those who came to see me or tried to get me to visit them that I had, for necessary business which required my immediate attention, an urgent, a supremely important appointment with myself" (Proust, Remembrance of Things Past, 3:1034-35).

"The idea of Time was of value to me for yet another reason: it was a spur, it told me that it was time to begin if I wished to attain to what I had sometimes perceived in the course of my life, in brief lightning-flashes ... at those moments of perception which had made me think that life was worth living. How much more worth living did it appear to me now, now that I seemed to see that this life that we live in half-darkness can be illumined, this life that at every moment we distort can be restored to its true pristine shape, that a life, in short, can be realized within the confines of a book! How happy would he be, I thought, the man who had the power to write such a book! What a task awaited him!" (Proust, Remembrance of Things Past, 3:1088). See Nehamas, Only a Promise of Happiness and On Friendship, for some of the most wonderful reflections on the love of art in contemporary philosophy. 
embodied in prayer. Eventually she gains a reputation for her wisdom and spiritual attainment, and, at the encouragement of church elders, develops theories about the methods and aims of ecstatic absorption with the deity. ${ }^{13}$

I hope that these examples depict the varied objects and life circumstances that occasion the experience of meaning. I hope also that they begin to motivate my conviction that this experience is most reliably caused by three main phenomena: life structure, susceptibility to rich and spontaneous emotion, and susceptibility to pleasing states of engagement and affection. This is the bedrock of the tripartite theory I will elaborate on in later sections. For now I offer some preliminary observations.

Max's love for Sherry structures his life. He devotes more time and energy to promoting Sherry's good than to addressing the flourishing of other beings and things he does not love; he spends more time with Sherry than with others; he cares more about getting her what she wants. Exactly the same can be said of Nancy and Kevin, though Alicia's sad fate will change this for Nancy. ${ }^{14}$ And while the cases of Marcel and Teresa may seem different, these appearances are superficial.

It is true that the activity of writing cannot feel pain. But it is nonetheless plausible that Marcel's writing can go better or worse, and it is plausible that Marcel's commitment to writing involves dedication to its progressive development. (Parallel claims about his book are also compelling.) Moreover, it is obvious that Marcel's craft structures his life, and that he may care more about writing than about even his closest friends and relations.

Some readers may look upon Teresa's case as a curiosity, because they believe that her love is in some sense undermined by an illusory belief in God's existence. But it is unfair to assume that Teresa's beloved does not exist. And it is worth observing that many of us love on the basis of profound illusions. Whether or not

13 "Now it seems to me that, when God has brought someone to a clear knowledge of the world, and of its nature, and of the fact that another world (or, let us say, another kingdom) exists, and that there is a great difference between the one and the other, the one being eternal and the other only a dream; and of what it is to love the Creator and what to love the creature ... when one understands by sight and experience what can be gained by the one practice and lost by the other, and what the Creator is and what the creature, and many other things which the Lord teaches to those who are willing to devote themselves to being taught by Him in prayer, or whom His Majesty wishes to teach-then one loves very differently from those of us who have not advanced to that stage" (Teresa of Ávila, The Complete Works of Saint Teresa of Jesus, 27).

14 As I will note later, my account of love suggests interesting results about the possibility of loving the dead and other nonexistent objects, and about the nature of grief. 
God exists, there is no doubt that commitment to Him structures Teresa's life as pervasively as any commitment structures most of ours. ${ }^{15}$

So the first important similarity among my cases is that love involves an intense commitment that crowds out commitment to other things. The examples of promoting the beloved's good and spending time with the beloved are two special but non-exhaustive cases of love's intense and constitutive form of commitment, which I call devotion, and explore in what follows.

A second important similarity is that the relevant psychological condition accounts for many of each of the protagonist's strongest emotions. It would be condescending, and clearly false, to insist that Kevin, Marcel, and Teresa could not have their most powerful emotional attachments directed at Orson, the craft of literary composition, and God, respectively. (Whether their attachments are rational or laudable is a separate question.) The emotional sensitivity that is rooted in intense devotion I call vulnerability.

Third, the devotion of my protagonists is a response to, and expressive of, an affectionate engagement with the object in question. In other words, they find pleasure or satisfaction in engaging with their beloveds. This observation is important for explaining how their cases differ from others that do not reliably lead to the experience of meaning. In my terminology, liking something is a key to meaning-generation.

Some readers may find my ideas so far unremarkable. I have not claimed that my views about the objects of love are wildly original. I have claimed that moral philosophers often ignore them. I will now defend this assertion more directly. Once I have shown that the notion of love that interests me is distinct from the notion of love that has interested most contemporary philosophers, I will proceed to explore it in more psychological detail.

\section{LOVE FOR PERSONS}

Contemporary philosophical inquiry into the nature and normative status of love has been dominated by a focus on the admittedly central case of love for persons. This focus has been both implicit and explicit. I have elsewhere given arguments for thinking the general tendency is worth interrogating. ${ }^{16}$ In this

15 Does God benefit from the love of believers? Now that is a chestnut. Either way, contemporary philosophy would benefit from sensitivity to cases like Teresa's, which have at other points in history been at the core of humanity's thinking about love, meaning, and morality.

Shpall, “Love's Objects." Compare also Plato's Symposium and Freud's homage (see the citation at Lear, Love and Its Place in Nature, 140): "Libido is an expression taken from the theory of the emotions. We call by that name the energy ... of those instincts which have to do with all that may be comprised under the word 'love.' The nucleus of what we mean by love 
section I hope mainly to establish two simple claims: first, that a narrow focus has been widespread, and second, that it has resulted in accounts of the nature of love that cannot apply to many of the cases I have taken to be paradigms of meaning-generation. Having done this, I will then criticize one idea that, if true, might threaten my approach: the idea that personal love is sufficiently normatively distinctive to make it the only kind of love truly relevant to moral philosophy.

Again, my primary intention is not to criticize other writers individually. They have various sensible reasons for offering more restricted accounts of love. The aim is to illustrate the relative advantages of my attempt to understand love via its connection to meaningfulness, without making stipulations about its possible or appropriate objects.

Here are a few representative examples of prominent philosophical theses about love. ${ }^{17}$

On J. David Velleman's Kantian conception, love is an arresting awareness of value in a person, a condition of intense emotional vulnerability that responds to another person's rational will. While Velleman notes that his characterization of love can also capture examples of vulnerability to other objects, he does not endeavor to say much about such cases. ${ }^{18}$ The distinctively Kantian idea presented in his luminous essay-that love is a moral emotion directed at instantiations of rational agency - could not be easily employed in such an explanation. In later work, Velleman emphasizes the distinctiveness of love for persons, and contrasts it with what we often call love for other objects, which he labels "benevolent affection." ${ }^{19}$ Indeed, Velleman here argues explicitly that so-called love for dogs is rooted in an illusion: the illusion of personhood in our furry friends. ${ }^{20}$

For Niko Kolodny, love is a particular mode of valuing, the valuing of a rela-

naturally consists (and this is what is commonly called love, and what the poets sing of) in sexual love with sexual union as its aim. But we do not separate from this-what in any case has a share in the name 'love'- on the one hand, self-love, and on the other, love for parents and children, friendship and love for humanity in general, and also devotion to concrete objects and to abstract ideas.... We are of the opinion, then, that language has carried out an entirely justifiable piece of unification in creating the word 'love' with its numerous uses.... By coming to this decision, psycho-analysis has let loose a storm of indignation, as though it has been guilty of an act of outrageous innovation. Yet it has done nothing original in taking love in this 'wider' sense. In its origin, function, and relation to sexual love, the 'Eros' of the philosopher Plato coincides exactly with the love-force, the libido of psycho-analysis." Many more can be found in the helpful set of references in Helm, "Love," which explicitly restricts discussion to personal love.

Velleman, "Love as a Moral Emotion," 365.

Velleman, "Beyond Price."

See Velleman, "Beyond Price," 203, and, for criticism of this commitment, see Kennett, 
tionship. Kolodny is clear that the relationship that concerns him, and that in his view occasions the special interest of moral philosophers, is one that necessarily involves persons:

On the one hand, I understand love exclusively as a state that involves caring about a person. However, it is perfectly correct English to say that someone "loves" something that is not a person... "Love," in ordinary usage, attaches to more than the psychological state with which I am concerned.... My narrowed focus is, I hope, acceptable. The species of love that involves caring for another person is the species that most attracts the interest of moral philosophers. ${ }^{21}$

Bennet Helm argues that love is intimate identification, or a kind of "taking to heart" of the beloved's identity, where this identity is understood to be something like the perspective of an autonomous human agent. ${ }^{22}$ Troy Jollimore conceives of love as a special mode of seeing a person, which involves sympathetic and appreciative contact with the beloved's qualities, and especially with her subjective experience of the world. ${ }^{23}$ Though Helm and Jollimore recognize that we often take ourselves to love things that are not persons, they believe that this tendency is unfortunate. Love for persons is psychologically and normatively distinctive, and deserves its own philosophical theory. ${ }^{24}$

More restricted targets are also common. Kate Abramson and Adam Leite explore the variety of love that they conceive of as a reactive emotion, which is a response to a good will. ${ }^{25}$ Other philosophers give accounts of romantic love, a special kind of intimate love for an agent's character, or, less commonly, close friendship. ${ }^{26}$

None of these treatments can apply to the cases in which Kevin, Marcel, and Teresa figure. Nancy's case is also troubling: Claire is not a person, and will never become one. It would be odd to think that Nancy's love for her can be described in terms of appreciating rational agency or valuing an interpersonal relationship.

"True and Proper Selves," 219-20. See also Millgram, "Kantian Crystallization," for a general critique. I discuss Setiya's similar treatment (in "Love and the Value of a Life") below.

Kolodny, "Love as Valuing a Relationship," 136-37.

Helm, Love, Friendship, and the Self.

Jollimore, Love's Vision.

See Helm, Love, Friendship, and the Self, 2, and "Love"; and Jollimore, Love's Vision, xii. Abramson and Leite, "Love as a Reactive Emotion."

On romantic love, see, e.g., Brogaard, On Romantic Love; de Sousa, Love; and Jenkins, What Love Is. On intimate love for an agent's character, see Bagley, "Loving Someone in Particular." On close friendship, see Nehamas, On Friendship. 
These observations show that my focus is uncommon. Before offering my account of love, however, it may be worthwhile to reflect on the normative distinctiveness of personal love, since it is very likely judgments about its distinctive value that explain the shape of our discourse. ${ }^{27}$

Love for persons is morally distinctive in at least the following ways. It tends to be more valuable than many or all other forms of love. Call this the average value claim. And it is in fact one of the most common kinds of love in human life. Call this the prevalence claim. These truths are important. Yet they do not cast doubt on the contention that other forms of love are also valuable and central sources of meaning. Indeed, these truths are compatible with the controversial idea that many people should pursue forms of nonpersonal love more actively, sometimes in place of personal love-an idea that I find plausible, significant, and underappreciated by philosophers and nonphilosophers alike.

What sort of judgment about value would explain and vindicate a philosophical discourse about love that ignored nonpersonal cases, if the average value and prevalence claims are insufficient? The relevant claim might be that love for a person necessarily realizes a distinctive kind of value-distinctive in the sense that the value of any other kind of love cannot be compared to it, or is necessarily inferior. These distinctive value claims are hard to formulate adequately and hard to evaluate. I am unsure which of my interlocutors accepts them. ${ }^{28}$ Moreover, I do not need to deny them in order to convince the reader that my approach is worthwhile. Even if Marcel's love could not be compared to Max's love, or was necessarily inferior to it, I would remain convinced that Marcel's love is important and that moral philosophers should be interested in it. Nonetheless, I am inclined to reject distinctive value claims, and will say a few words on this score.

A first reason for doubt is that it can be appropriate to abandon personal love. This indicates that personal love may be less valuable than other things. Consider an abused woman who loves her abusive partner. Suppose she leaves him, finally resisting her impulse to stay after a long struggle with the recognition that her love is toxic. One description of her leaving: she has compared her love for her partner to other values that it threatens-for example, her love for her cats, her

27 See the Kolodny passage above; Velleman, "Beyond Price," where it is claimed that personal love is especially "fierce"; Helm, Love, Friendship, and the Self, where it is claimed that personal love is especially "deep"; and Bagley, "Loving Someone in Particular," 480, who claims that a particular form of personal love, grounded in appreciation of character, is the "best kind of love." Compare also Fromm, The Art of Loving, 20, for whom interpersonal love is "the mature answer to the problem of existence." 
love for her work, her love for herself-and judged her romantic love to be less important. ${ }^{29}$ The aptness of this description would raise questions about both the comparison and inferiority versions of our idea about personal love's distinctive value.

Second, I am inclined to endorse the view that some people are unworthy of love. It was inappropriate for some who loved the adult Hitler to love him. It would have been far better for these Hitler lovers to love other things instead. The example is divisive and will not move everyone. For the sympathetic, however, it may serve as a reminder that some personal love is not just imprudent, but regrettable or even evil.

Third, I should emphasize the dialectical situation for proponents of a distinctive value claim. Their contention is that love for a person necessarily possesses value properties that no other kind of love can possibly possess. The negation of their claim is a far more modest possibility thesis.

Finally, I present a thought experiment for the reader to chew on, which indicates to me that many people already accept such possibility theses. For simplicity's sake, I limit myself to one comparison of personal love with love for aesthetic objects such as artworks. But further examples of similar kinds might be contemplated involving putative love objects such as infants, humans in profoundly deteriorated cognitive states, nonhuman animals, activities, works of art, deities, cities or nations, natural wonders, cultural endeavors, and social or political causes. ${ }^{30}$

Imagine the following distant variant of a "one thought too many" case. ${ }^{31}$ In order to save the collection of paintings in the Van Gogh Museum, which is about to be set afire by an accomplished arsonist, an art-loving museum curator must immediately rush to intercept the perpetrator. But doing so will force her to miss a critical medical procedure that cannot be postponed. The procedure

Love for oneself is love for a person. But it is unclear which of the most prominent accounts of love can capture it. Compare Soble, “Concerning Self-Love," and Frankfurt, The Reasons of Love.

You might think invoking the cases of love for infants or people in degenerated states in this particular argument is cheating, since philosophers interested in personal love must be interested in such cases as well. This is too quick. Most leading accounts cannot be extended so easily. For discussion, see Shpall, "Love's Objects." For remarks on the love of country and of nature, see Lewis, The Four Loves, ch. 2. For more questionable examples, see Nelson, Bluets, on love for the color blue; and Charles, "A Crime of Passion," on the love of yogurt. (Thanks to Michael Hardimon for the latter reference.) What distinguishes the boundaries of the lovable? I hope the tripartite theory gives us some purchase on this question without settling it too hastily. One set of ideas about the possibility of loving humanity will arise later, when I have said more about the nature of devotion. 
would extend the curator's life for around six to twelve months; without it, she will die within the year. Choosing to save the paintings is, in other words, also choosing to shorten her life, choosing to spend less time with her husband and children and grandchildren, and so on. My conjecture is that at least some art lovers in this position would sacrifice their personal loves for the sake of the Van Goghs. (If you prefer a more mundane analogue, consider the claim that some artists would choose the completion of a beloved work over an extension of their own lives.)

Kieran Setiya makes a subtly different claim about moral distinctiveness, which might be thought more compelling than the idea I have just discussed. ${ }^{32}$ I conclude this section by quickly addressing it. According to Setiya, the bare property of being human justifies love, and specifically justifies love of a form that involves partiality in action. ${ }^{33}$ It can be rational, for example, to act from love and save one's wife from drowning instead of saving three strangers. Now Setiya is surely correct that love involves, and to some extent justifies, partiality in action. But is this feature of justified partiality connected to love of human beings in particular, or love as such? It seems to me obvious that love for human beings is not distinctive in having implications for justified partiality. If Setiya is right about the permissibility of saving his wife instead of three strangers, it should likewise be permissible for him to save his puppy over three strange puppies, or the lone copy of his beloved unpublished manuscript over three strangers' similarly beloved and endangered works. The distinctive value here is general, inhering in love for many types of objects. ${ }^{34}$

In sum: love for persons is one of the most valuable, common, and interesting forms of love. Human lives usually merit preservation and care more than other valuable objects do. But these facts do not make me any less interested in understanding love as a general psychological kind. On the contrary, they make me more curious about how to integrate love of different sorts into a flourishing life that is filled with the experience of meaning. Authors interested in the special case of love for persons are, as I have made clear, perfectly entitled to analyze it and it alone. We should nonetheless recognize that the dominance of

32 Setiya, "Love and the Value of a Life."

33 Though he is much indebted to Velleman ("Love as a Moral Emotion"), Setiya makes humanity rather than personhood the locus of his conception of love and its reasons, in order to address cases like Talk to Her.

34 Some think it is always impermissible to, for example, save one dog instead of one human being, independently of whether you love the dog. I am not sure. Consider Kevin in a lifeboat case with Orson and a terminally ill stranger. It is worth noting that this popular impermissibility claim would, if true, raise serious moral questions about pet adoption, which involves a huge allocation of resources to a pet, and which many of us take to be permissible. 
this approach might limit us. ${ }^{35}$ I have been at pains to motivate the availability of a wider understanding because the views I will now advance are in many ways responses to a discourse dominated by an exclusive focus on love for persons.

\section{A TRIPARTITE THEORY}

I now present a theory of love that systematizes the central features of my paradigm cases, and provides a richer characterization of the psychological phenomena that could play the meaning-generating role animating this inquiry. My strategy is to decompose love into three main elements: devotion, vulnerability, and liking. That these are imperfect terms of art should be obvious. ${ }^{36}$

The three components are separable. They arise in different forms and degrees. Nonetheless, thinking about their individual natures and their potential combinations clarifies the differences between love and other psychological conditions. ${ }^{37}$

The most important feature of my account is that I conceive of love as constituted by intense devotion. The devotion is of a particular character, which I will analyze shortly. Crucially, it is devotion that renders vulnerable and expresses liking.

35 For one quick illustration of this danger, consider the idea that love is essentially a form of union, which has been pursued in different ways by Scruton (Sexual Desire), Solomon (About Love), Nozick ("Love's Bond"), and others (including its foundational presentation by Aristophanes in the Symposium). The idea may seem plausible when we only consider certain central cases of love for persons - and particularly the case of erotic love, which is the focus of most union theorists. (There are compelling worries about even this particular case. Healthy romantic love does not swallow up our interests or our autonomy. See Helm, "Love," and Bagley, "Loving Someone in Particular.") But it will be especially hard to vindicate a view like Scruton's, which has it that there is no distinction between the lover's interests and the interests of his beloved, when the beloved is an elephant or a national park. An expanded focus on a variety of examples, including cases of love for nonhuman animals and non-sentient objects, can be a valuable source of insight, and can inform our understanding of love for persons as well.

There are affinities here with the work of the psychologist Robert Sternberg, "The Triangular Theory of Love." I cannot discuss the relationship between my account and Sternberg's Triangular Theory at any length but will note that Sternberg is, like many contemporary philosophers, only interested in love for persons.

A reviewer worries that there is a tension between my composite characterization of love and my claim that love is a distinctive psychological condition. But various psychological conditions are composite yet distinctive. There are connections here to work in the psychology and philosophy of emotion, work that is too often neglected in writing about love. A useful introduction to some central debates is Griffiths, "Current Emotion Research in Philosophy." 
I hope that the virtues of this account will become apparent to the reader. But I will mention three at the outset: (1) It is an elaboration of an attractive moral psychology of love, one that is more detailed than many predecessors. ${ }^{38}$ (2) It is controversial and distinct from existing views-even when it resembles them. (3) It gives us traction on puzzling intuitions about love's connection to rational agency, as well as new insights about choice points for further theorizing.

One way to frame my picture of the nature of love, and to compare it to competing accounts, is by appealing to a divide between cognitive, affective, and conative psychological states. There are legitimate worries about this taxonomy of the mind, and I will not attempt to argue for its defensibility. ${ }^{39}$ I will assume that most of us take belief, sadness, and desire to be somewhat helpful models of the cognitive, affective, and conative, and hope that readers will permit me to import these classifications without being overly encumbered by theoretical baggage. As should become clear, nothing much turns on this particular mode of division, though some of the most essential claims of alternative theories of love can be clarified by appealing to it.

For example, what Helm calls "Robust Concern Views," like those of Frankfurt, conceive of love as a form of noninstrumental caring. ${ }^{40}$ Proponents and critics alike understand such views as claiming that love is neither affective nor cognitive, but conative-volitional. Others think love involves cognition, in the form of value judgment-plausibly Velleman and Kolodny, but compare also Jollimore, who takes love to be an appreciative way of seeing a person. ${ }^{41}$ By contrast, the prevailing commonsense view is probably that love is a feeling or a mode of affect. Velleman's analysis of love's "arresting” of our emotional defenses is arguably a vision of this affective phenomenology, which Kant thought it so

Apart from some of the views already mentioned, compare Liao, The Right to Be Loved, ch. 4, and Ebels-Duggan, "Against Beneficence," 143, for compositional accounts with less articulated content.

See Helm, Emotional Reason; Nussbaum, Upheavals of Thought, esp. ch. 1; and Fricker, Epistemic Injustice, 72-81.

Helm, "Love”; Frankfurt, "Autonomy, Necessity, and Love" and The Reasons of Love.

Velleman, "Love as a Moral Emotion"; Kolodny, "Love as Valuing a Relationship"; Jollimore, Love's Vision. This assumes, against noncognitivists, that judgments of value express beliefs. Velleman ("Love as a Moral Emotion," e.g., 360-61) is an especially fascinating example of a writer who endorses a cognitive requirement on love, since he regards love as an acknowledgement of the value of the beloved independent of motives to benefit and be with, and, as I note later, views conative analyses of love as "aim-inhibited versions of Freud" that "replace the sexual aim identified by Freud with the aims of desexualized charity and affection." Velleman-love is a Murdochian exercise in "really looking," and hence essentially involves cognition, perception, and belief. 
important to reject-though Velleman's view is complex in its blend of judgment and affect, and there are subtleties in trying to characterize it adequately. ${ }^{42}$

My aim in introducing these distinctions between mental phenomena is minimal. The division I hope to exploit is the division between psychological states that involve our agency and those that do not-or, more precisely, between degrees of agency involvement. The key claim I will be invoking is the claim that devotion is a paradigmatically active or volitional condition. This distinguishes it from liking and vulnerability, which are much less active, even if they likewise involve or are associated with conation. It also distinguishes devotion from cognitive conditions like belief, awareness, and value judgment. ${ }^{43}$

\section{Devotion}

Being devoted to something is being especially concerned about it, and being disposed to act on this concern. It is having the disposition to choose it over other things. Metaphorically, being devoted is having the beloved object near the center of your volitional universe. To pilfer a phrase from Iris Murdoch: the most robust loving is a life-occupation. ${ }^{44}$

This is intentionally vague because it is common to implausibly narrow and moralize the nature of love's devotion, which in fact takes a variety of forms. A popular thought is that love involves a tendency to promote the well-being of the beloved, which is rooted in noninstrumental concern for them. ${ }^{45}$ And this is indeed one kind of devotion, an essential part of many recognizable forms of love, including nonpersonal love. For example, it is customary for art lovers to be devoted to art itself, and not simply to personal experiences of art. This is why

42 Velleman, "Love as a Moral Emotion." Compare Kant, The Metaphysics of Morals, 450: "Love is not to be understood as feeling ... or delight.... It must rather be thought as ... active benevolence." Velleman-love is, as I understand it, an arresting (affect) awareness (cognition) of the value of rational nature, as instantiated in a particular rational being.

43 Provided we reject cognitivist views about intention, which claim that intentions are special kinds of beliefs (e.g., Harman, "Practical Reasoning"; Velleman, Practical Reflection; Setiya, "Cognitivism about Instrumental Reason").

44 "All this may sound ridiculous. But being in love is a life-occupation. I suppose this concept resembles, or rather is a special case of, the idea of doing everything for God and making the whole of life into a sacrament" (Murdoch, The Black Prince, 204). My characterization will accommodate Velleman's point that we should be skeptical about positing necessary connections between loving and desiring particular outcomes ("Love as a Moral Emotion," 361), while maintaining that love is most essentially a matter of the will.

45 See Taylor, "Love”; Frankfurt; The Reasons of Love; Rorty, “The Burdens of Love”; and many others. For an excellent discussion of how the noninstrumental concern of lovers relates to ancient Greek eudaemonism, see Brink, "Eudaimonism, Love and Friendship, and Political Community." 
many wealthy art lovers fund museums and scholarships instead of acquiring private collections. Similarly, loving pet owners like Kevin often act in ways that frustrate their own interests but further the good of their pets.

But there are other kinds of loving devotion. As Aristotle emphasized, close friendships are characterized by a commitment to shared activity. ${ }^{46}$ As he did not emphasize, they are also characterized by devotion to the satisfaction of desires, even (at times) when such desire satisfaction detracts from flourishing. ${ }^{47}$ My view is that three forms of devotion are central to love, and distinct from one another: devotion to flourishing, end-promotion, and being-with. ${ }^{48}$ I think it is important to remain open-minded here. There is no fact of the matter about how much of each form of devotion is required for any particular form of love.

Plausibly only rational agents have their own ends, and this is one way in which appropriate love for them must be distinguished from appropriate love for other things. (Though I would stress that it is not obvious what beings count as rational agents, and also that many beings have desires whose satisfaction we might promote even if they do not have ends.) Then again, there are reasons for thinking that a certain species of being-with devotion is fundamental for meaning-generation. Though I cannot explore this proposal in detail, I think that Kieran Setiya is correct in arguing that the best response to one kind of midlife crisis is the adoption of "atelic" ends-or atelic orientations toward some of our activities. ${ }^{49}$ This means conceiving of activities as completed or fulfilled at every point of our engagement with them. As Setiya nicely puts the contrast between the telic and the atelic: you might write a philosophy paper not in order to finish or publish it, but in order to be doing philosophy. My thought is that being with our beloveds is the gold standard of atelic activity, which is what makes it the right kind of response to crises of meaning. ${ }^{50}$

46 Aristotle, Nicomachean Ethics.

47 See Nehamas, "The Good of Friendship," who argues that philosophical accounts of friendship are excessively moralized, because friendship is often a matter of sharing in trivial, banal, or even reprehensible activities. Compare also Cocking and Kennett, "Friendship and Moral Danger." And see Lewis, The Four Loves, 97: "Friendship (as the ancients saw) can be a school of virtue; but also (as they did not see) a school of vice. It is ambivalent."

48 See Ebels-Duggan, "Against Beneficence," for an interesting argument that love for fully functioning adults is a matter of devotion to their ends. The account is intended to outline a normative ideal, and so does not directly challenge the view that all three forms of devotion are partially constitutive of love, as I understand it. Bagley, "Loving Someone in Particular," proposes an object of devotion in some loving relationships that he calls "deep improvisation," and that may well be distinct from the three forms of devotion I explore.

Setiya, "The Midlife Crisis."

so Compare also Wonderly, "Love and Attachment," on the value of self-interested attachment in romantic love. 
Some of the most influential writers on love are skeptical about linking it to the will noncontingently. Velleman famously argues that conative conceptions are implausible descendants of a bunk Freudianism. ${ }^{51}$ Others agree, claiming that the active phenomena I have outlined are simply typical but non-necessary manifestations of love. ${ }^{52}$ Putative counterexamples to conative accounts include love for grown children and annoying relatives, which are said to sometimes lack any active orientation of will, such as a concern to help or promote well-being. ${ }^{53}$ Perceptive critics have noted that these examples are under-described and dialectically weak. ${ }^{54}$ Loving parents remain devoted to their adult children in all sorts of meaningful, if not grasping, ways. Our psychological connections to extended familial relations are extremely varied, and require careful differentiation before they can provide any general truths about love's nature. And, as I have just been arguing, love's devotion is not reducible to a moralized concern for the beloved's well-being. Even if they are not devoted to promoting other end-states (which I very much doubt), loving parents of self-sufficient adults are still devoted to spending time with their children.

Much more could be said about these examples and others like them. I cannot hope to establish the thesis that devotion is, as I believe, the core of love. But at a minimum my treatment suggests one way of conceptualizing a crucial choice we face in thinking about love's nature. Here is one way to put it. I can grant that there is some sense of love that is not active. But I maintain that my sense of love is the one that is most intimately connected to the perception of meaning. By way of illustration, let us consider a stronger case for the opponent of conative accounts-a case that deserves much more attention than it has received. To put it bluntly: Can we love the dead?

My claim is that the psychological condition most connected to the perception of meaning in life is essentially active. It follows that if it is possible to love the dead in my sense, then it must be possible to be devoted to them. I believe this to be a plausible consequence. If the dead have interests, then it is possible to be devoted to these interests. This may suffice for being devoted to the persons

51 Velleman, "Love as a Moral Emotion."

52 See Badhwar, "Love." Nussbaum agrees: "Love is a particular kind of awareness of an object, as tremendously wonderful and salient, and as deeply needed by the self. The project of possession (or of helping) is then a response to that awareness" (Upheavals of Thought, 477). Susan Wolf is instructively ambivalent on the issue. At times (e.g., The Variety of Values, 188) she expresses skepticism akin to Velleman's. But elsewhere (Meaning in Life and Why It Matters, 9-10, 26) she emphasizes that love must be "active" in order to adequately connect with meaningfulness.

Velleman, "Love as a Moral Emotion."

54 E.g., Helm, "Love”; Abramson and Leite, "Love as a Reactive Emotion." 
themselves. (I am unsure.) Independently, some believe that such devotion is possible, because they believe in a personal afterlife. These people can presumably be lovingly devoted to those who have passed away. They are in Teresa's situation, if we suppose that God does not exist.

However, it is much harder to find meaning in a purely backward-looking, largely passive condition of remembrance. This does not imply that the life of a person without living loves is meaningless. There is of course some meaning to be found in remembrance, and in other psychological conditions, experiences, and relationships. ${ }^{55}$ But the creation of new meaning in life is most characteristically the product of a special form of devotion, and the absence of devotion causes the deterioration of the experience of meaning. Some readers will find this point obvious. Those who want more evidence might reflect on familiar concerns about the psychological health of elderly people, particularly those separated by death from their friends and partners, and by distance from their living relatives. ${ }^{56}$

These reflections cohere with another commonplace intuition. We are skeptical when someone claims to love something but has exhibited little devotion to it. Statements of the form, "If you really loved $X$, then you would $Y$," typically invoke actions or intentions that the agent in question apparently lacks, and are our default formulations of love-denial. ${ }^{57}$ The force and ubiquity of these skeptical judgments is evidence that love is not merely contingently related to devotion. Again, this argument does not and could not prove that my conception of love is the best one available. No such arguments are forthcoming for any controversial view about this difficult topic. The best we can do is to gather up interesting evidence for rival conceptions, and evaluate this evidence in fresh ways.

It may be worth observing how my treatment of devotion distinguishes the idea of love articulated here from some influential traditions. Love in my sense involves sustaining an object near the center of your volitional universe, so it must be sharply distinguished from respect, goodwill, impartial benevolence, what I would call loving-kindness, and common understandings of agape that are connected to some of these notions. ${ }^{58}$ Still, there might be some nonmeta-

I have nowhere maintained that only love can generate the experience of meaning.

Grief is in part a response to the loss of a focal point for one's volitional universe. It is no surprise that a strategy for coping is the adoption of new ends in the form of pets, activities, and cultural appreciation. The special susceptibility of the elderly to the loss of love and meaning, particularly in societies structured like ours, is a matter of great moral consequence.

See Fromm: "No assurance of [a mother's] love would strike us as sincere if we saw her lacking in care for the infant, if she neglected to feed it, to bathe it, to give it physical comfort.... It is not different even with the love for animals or flowers" (The Art of Loving, 25). Compare Ferracioli, “The State's Duty to Ensure Children Are Loved” 6.

58 See Nehamas, On Friendship, 50-51. Compare Aristotle: "Goodwill would seem to be a 
phorical sense in which love for humanity (or love for elephants, or love for the cinema) can be expressed in devotion to, say, particular individuals, activities, and projects. This issue has divided philosophers for a long time, and I will not presume to settle it.

I conclude this discussion of devotion with a puzzle. The mental state of intention involves a practical commitment. ${ }^{59}$ Indeed, it is natural to regard intention as the volitional state par excellence. So we might try to understand devotion as a robust pattern of intentions involving the beloved, which make up a holistic and directed structure of the will. ${ }^{60}$ But this account may not suffice. Consider:

Untimely: Florentino loves Fermina madly. But he cannot devote himself to her in any ways that might be observed by others, since Fermina is married to Juvenal, and any displays of Florentino's love would have terrible consequences. ${ }^{61}$

The worry is that my emphasis on devotion requires me to deny that love can be hidden or unexpressed.

One important response is to insist that if Florentino truly loves Fermina, his intentions will in fact be structured around her, even in these sad circumstances. For example, Florentino may be devoted to thinking about Fermina every night, praying or planning for opportunities to meet her surreptitiously, and remaining romantically uncommitted.

But I find the spirit of the worry persuasive. So I prefer to analyze devotion as a combination of occurrent intentions and dispositions to intend. My formulations throughout this section have respected this ambiguity. Some of Floren-

feature of friendship, but still it is not friendship. For it arises even toward people we do not know, and without their noticing it, whereas friendship does not" (Nicomachean Ethics, 143). Since God has an infinite will, he may have mankind (or all Creation) at the center of His volitional universe. We must be more discriminating.

On Bratman's influential view (Intention, Plans, and Practical Reason, 107-10), intentions control conduct and structure deliberation. Intending to A now normally leads one to try to $A$; intending to $A$ in the future normally survives to become an intention for the present. And an intention to $A$ characteristically persists through time and exerts pressure against reconsidering whether to $A$. Additionally, an intention to A structures deliberation by disposing one to reason about means to $A$, and by disposing one to refrain from forming new intentions that are incompatible with $A$. See also Harman, Change in View, 94-95.

60 Compare Frankfurt, "On Caring" and The Reasons of Love, but with a more pluralistic account of the content of the relevant intentions, and the caveat that Frankfurt might reject my claims about vulnerability and liking.

61 "'Fermina,' he said, 'I have waited for this opportunity for more than half a century, to repeat to you once again my vow of eternal fidelity and everlasting love" (García Márquez, Love in the Time of Cholera, 64). 
tino's devotion may be masked by his unfortunate circumstances, just as the fragility of a glass may be masked when it is packaged. Still, these partially masked dispositions to intend to hang out with Fermina, promote her interests, and so on, are the heart of his love. ${ }^{62}$

Now for our puzzle. I have just argued that devotion can be constrained or denied expression by external contingencies. It is hard to devote oneself in the normal ways while held in solitary confinement, for example. ${ }^{63}$ Since most of us believe that confinement or separation does not always extinguish love, we are committed to the plausible view that, insofar as devotion is required for love, it can at times be realized in mere dispositions. However, there also appear to be limits to the adequacy of such purely dispositional claims. The puzzle concerns how we are to draw these boundaries.

Suppose a heroin addict feels that he loves his infant son, and has various dispositions to be devoted to him. Nevertheless, this man invariably ignores the child, overcome by, or giving in to, his stronger dispositions to get high. ${ }^{64} \mathrm{I}$ believe we should say, in at least some sufficiently bleak cases of this kind, that the man does not love his son, or does not love him in the sense of love articulated by the tripartite theory. I suspect that the root of this reaction is due to the swamping dispositions being internal to the agent-he is to some degree directly responsible for them-rather than being imposed from the outside. ${ }^{65}$ But I am not confident in this idea, cannot defend it here, and will simply leave

62 Compare Goldie, “Love for a Reason," and Naar, "A Dispositional Theory of Love,” on love as a disposition.

63 For extraordinary reflections on a more familiar example, see Aristotle, Nicomachean Ethics, 124-25: "Just as, in the case of the virtues, some people are called good in their state of character, others good in their activity, the same is true of friendship. For some people find enjoyment in each other by living together, and provide each other with good things. Others, however, are asleep or separated by distance, and so are not active in these ways, but are in the state that would result in the friendly activities; for distance does not dissolve the friendship without qualification, but only its activity. But if the absence is long, it also seems to cause the friendship to be forgotten; hence the saying, 'Lack of conversation has dissolved many a friendship." Soon after, Aristotle continues: "Those who welcome each other but do not live together would seem to have goodwill rather than friendship. For nothing is as proper to friends as living together." This marvelous passage has brought me an odd mix of painful recognition and consolation.

64 See Naar, "A Dispositional Theory of Love," 347, for discussion of a similar case involving depression.

65 Compare Aristotle, Nicomachean Ethics: "Voluntary action seems to be what has its principle in the agent himself" (32). Some readers have claimed that we cannot control dispositions, and thus worried that by countenancing dispositions to intend I give up on the volitional character of devotion. This cannot be right. Present-directed intentions are themselves dispositions. The relevant distinction is between dispositions to intend that we can 
the reader to consider whether the embryonic distinction I have drawn has any significance. I hope it is clear that the puzzle is not necessarily an objection to my view. If the case is genuinely perplexing, then illuminating accounts of love will reveal why, rather than dissolving the puzzle without trouble.

I will make one final observation about Florentino's case. I agree that he lacks many of the forms of devotion normally constitutive of romantic love. But we should notice how much this explains. What Florentino wants is to be able to express his love for Fermina by devoting himself to her. Insofar as he cannot do this, or is substantially constrained in the ways he can do it, his situation is lamentable. After all, there is a special pain in unexpressed love, beyond a lack of reciprocation. ${ }^{66}$ Even sure-to-be-unrequited love often seeks expression. The tripartite theory gives voice to this dynamic drama. If we lose all opportunities to "express our love," we eventually lose the love itself. ${ }^{67}$

\section{Vulnerability}

Vulnerability is the least controversial element of my account. It is most commonly associated with Velleman's articulation of love's phenomenology, which outlines a special form of emotional receptivity that involves the breakdown of mechanisms of self-protection. ${ }^{68}$ What I call vulnerability is implied by Velleman-vulnerability, but my claims about its nature are less ambitious.

To be vulnerable to an object of love is to be especially disposed to have strong emotions (for instance joy, heartbreak, pride, shame) conditional on the obtaining of states of affairs in which the object figures. When something bad happens to a beloved we feel pain, and we feel pain in part because we care about the beloved in her own right. Here we have an undeniable gulf between love and other relations of association. Those of us who are not saints might be pained by the terrible fates of casual acquaintances, but this resembles the parallel pains of love like shadows resemble forms. ${ }^{69}$ To put the point in its more classical formu-

endorse and sustain, and those (e.g., unconscious desires) whose motivational operation does not involve our agency in these ways.

66 See Austen: "In vain have I struggled. It will not do. My feelings will not be repressed. You must allow me to tell you how ardently I admire and love you" (Pride and Prejudice, 128).

67 Compare another enigmatic Murdoch metaphor: "We cannot really love the dead. We love a fantasm that secretly consoles" (The Black Prince, 342). I already noted how we could avoid this conclusion, but it is worth stressing that my view makes it far from trivial to explain love for the dead in some cases, and that I think this is a virtue.

Velleman, "Love as a Moral Emotion" and "Beyond Price."

69 There is a sense in which we genuinely value strangers. However, since we remain largely unperturbed by many distant tragedies, it seems obvious that it is in another sense that we value what we love. Plausibly this is because "value" is ambiguous: sometimes it refers to 
lation: we feel bound to what we love, and in an important way we share its fate. ${ }^{70}$

To be vulnerable is to have lost control. Someone you love might move away, or start treating you with meanness, or shower you with new warmth, without your having done anything to precipitate it. Lovers are necessarily exposed to largely unmanageable sources of happiness, devastation, and the like. So while we may exercise substantial control in coming to love, loving itself renders us less emotionally autonomous. Jeanette Kennett puts it this way: "Love takes us hostage to fortune; it binds us to the weal and woe of the beloved in ways we could not have anticipated and cannot reject." 71

But vulnerability is not unique to personal relations. Losing a pet, suffering a career-ending injury, or confronting the demise of one's long-term artistic or political ambitions can be devastating - more lasting and existential in its heartbreak, for some, than losing a beloved grandmother or boyfriend. ${ }^{72}$ It may be irrational to have some of these patterns of vulnerability, but nobody said that human beings are never misguided in love. What seems clear is that love is partially constituted by these emotional dispositions. If you are not much moved by the fortune of something, this seems like pretty conclusive evidence that you do not love it. ${ }^{73}$

The tripartite theory's distinctive and controversial claim about vulnerability is that it is explained by devotion. I conclude this section with an argument for this explanatory claim. The argument is familiar from the philosophy of emo-

judging valuable, and other times it refers to caring. Only intense forms of caring render us vulnerable in the sense I am after.

70 The formulation recalls "union" views without endorsing them. Compare Prov. 14:10: "The heart knoweth his own bitterness, and a stranger doth not intermeddle with his joy." We can interpret this wonderful sentence as expressing the view that only those who love us really feel for us. (Although I suspect this may be to interpret it erroneously, if we mean to widen the ambit of non-strangers beyond God!) A more direct and equally beautiful illustration, which I owe to Gabriel Citron, is a famous story about Rabbi Aryeh Levin: "And indeed, when his own good wife Hannah felt pains, he went with her to Dr. Nahum Kook and told him, 'My wife's foot is hurting us'” (Raz, A Tzaddik in Our Time, 150).

71 Kennett, “True and Proper Selves: Velleman on Love," 217. See also Nehamas, Only a Promise of Happiness, 57, and On Friendship, 136. There are interesting comparisons to Frankfurt's conception of volitional necessities (e.g., The Importance of What We Care About, ch. 7) that I cannot explore.

72 See Philippa Foot's excellent discussion of "deep happiness" (Natural Goodness, 87), and her claim that even "things that do not really matter-like a bad faux pas, or the non-arrival of an invitation to a party of the Duchesse de Guermantes - can create any amount of disturbance, right up to obsession."

73 Although here again we must worry about the types of masking cases I discussed in framing the puzzle about devotion. 
tion, but it is not often invoked in writing about love. ${ }^{74}$ It supports the general claim that emotions are concern-based. In other words, they are grounded in or explained by concern.

Why do I fear for my garden's fate in the coming storm? I am afraid because I value my garden's flourishing. Why am I over the moon about my sister's engagement? I am joyful because I care about my sister's happiness. Why am I upset about gerrymandering? I am upset because democratic ideals matter to me. Generalizing: concern (or something in the ontological neighborhood) is part of what explains emotion.

The argument looks good prima facie. Since vulnerability as I understand it is a disposition to have strong emotions, the concern-based nature of emotions would make it likely that vulnerability is also concern-based. I have maintained that devotion is an especially strong form of concern (practical commitment, intention, structure of will). It seems plausible, then, that intense vulnerability is explained by intense devotion. ${ }^{75}$

\section{Liking}

Liking is the third element of the tripartite theory. That it is substantially less agential than devotion is the prevailing and intuitive view. ${ }^{76}$ This contrast goes a long way toward explaining our complex and ambivalent intuitions about love's relationship with rational agency. I return to this point in my concluding remarks.

Many philosophers think that we can love without liking. ${ }^{77}$ Concerning the sense of love under consideration, which is constitutively tied to meaning, I think they are wrong. Again, a virtue of the tripartite theory is that it clarifies this conceptual fault line. I hope that the ensuing reflections also provide some new considerations that bear on how we should proceed.

To like something is to be disposed to enjoy it, feel affection for it, experience attraction to it. There are deep connections between liking and desiring. If you like skiing, then, other things equal, you desire to $\mathrm{kii}^{78}$ It is a commonplace

Cf. Roberts, Emotions.

Compare Helm, Love, Friendship, and the Self, and Smuts, "Normative Reasons for Love, Parts I and II," 510.

6 Cf. Liao, "The Right of Children to Be Loved," 427.

See Velleman, "Love as a Moral Emotion"; Setiya "Love and the Value of a Life”; Wolf, The Variety of Values, 190; and Frankfurt, The Reasons of Love, 42. Cocking and Kennett ("Friendship and the Self," 519) and Nehamas (On Friendship, e.g., 109, 132) think that liking is part of loving, at least in the case of friendship. Badhwar, "Love," is an insightful proponent of the general love-liking connection. But explicit endorsements of the liking condition are rare, and arguments for it are almost never articulated. 
in philosophical psychology to treat desire as the fundamental pro-attitude, the state with world-to-mind direction of fit that we need, in addition to belief, in order to explain human action..$^{79}$ But liking and wanting are different, and I think it is preferable to concentrate on the relationship of liking to loving. ${ }^{80}$

Liking something is compatible with finding it frustrating and with a host of other negative emotions. The claim here is not the manifestly absurd one that love involves unqualified hedonic stimulation. The claim is that devotion, even devotion that renders vulnerable, only plays the robust meaning-generating role if you like the object to which you are devoted.

In ordinary English, loving and liking appear intimately connected. But the surface of our language might be confusing. One source of skepticism about the merits of a pluralist account of love's objects is the perceived cheapness of some love attributions. The word love plausibly has multiple functions, some of which fail to cut the mind at its joints. For instance, it commonly picks out relatively superficial states ("I love this mint chip ice cream") that seem more like bare enjoyment, and unhelpful in thinking about the love that interests us here. ${ }^{81}$

Still, our linguistic intuitions may provide us with some information. The claim that you love a nonhuman object but do not like it has a paradoxical ring. If you love writing fiction then you like writing fiction-though you might not like particular aspects of it, and some stretches of writerly life may be hard going. ${ }^{82}$ If I am right that liking is not merely incidental to loving in such cases, then this is a piece of evidence for any analysis of love that aspires to object-generality.

Suppose Max's brother Mark claims to love Sherry, but it appears that he does not like spending time with her, does not take any satisfaction from the maintenance of their relationship, and has mostly negative reactions to even thinking about her. There is something unsettling but also incongruous about this apparent combination of attitudes. And it seems importantly different from

connections between pleasure and desire.

79 See, e.g., Smith, The Moral Problem, and Sinhababu, "The Humean Theory of Motivation Reformulated and Defended." Frost ("On the Very Idea of Direction of Fit") has recently attacked the philosophical convention of explicating mental states partially in terms of direction of fit. I cannot engage with his stimulating arguments here, and the reader need not accept the convention in order to make sense of my views.

80 Berridge, "Wanting and Liking."

81 For this worry, see Helm, Love, Friendship, and the Self, 2, and "Love." Rorty, "The Burdens of Love," 347, seems too quick to take our language as dispositive.

82 Fiction writers sometimes claim that their craft is pure anguish. This seems hyperbolic insofar as they also claim to love writing. Machado describes personal love in a way that I think generalizes: "We love each other all of the time and like each other most of the time" (“Mothers," 55). 
Max's psychological orientation in World's Best Mom, which I offered as a paradigm case of filial love. Though we do sometimes make claims about loving persons without liking them, it is not clear that we should take these assertions at face value. For example, "I don't like you, but I love you" may just convey something like, "I love you, but you've been acting like an asshole." ${ }^{83}$

Nonetheless, many dismiss the love-liking connection. In the remainder of this section I consider a case that I take to best express their worries. The discussion will permit me to reflect on some of my dissatisfactions with common arguments, and will hopefully illustrate some distinctive features of the tripartite theory.

Lost Cause: Jill has always been a model mother to her son Beelzebub. Sadly, Beelzebub's moral deterioration has reached a point of no return. Jill remains devoted to her son. She does everything she can to help him and to spur some kind of change in his perspective and way of life. However, she is consistently unsuccessful in bringing about meaningful change, and is tortured by the situation. After years of soul-searching, Jill finally confesses to her analyst that even the last dregs of motherly affection have disappeared. ${ }^{84}$

Some philosophers are explicitly committed to claiming that Jill loves Beelzebub, even though she does not like him. And it is plausible that many philosophers who do not discuss examples of this sort nonetheless implicitly endorse the conclusion, since they conceive of love as a specific kind of emotional vulnerability, attachment, union, identification, care, or valuing, and each of these conditions can in principle be directed at objects we do not like.

83 This is how I interpret the iconic phrase of Smokey Robinson's in "You've Really Got a Hold on Me." (Thanks to Gary Watson for the fantastic reference.) A related example, which I owe to Jacob Ross, is from David Bowie's "Drive-in Saturday": "She's uncertain if she likes him/But she knows she really loves him." Poetry is often forged from twists in our conceptual expectations. We can see something interesting in these lines without thinking they constitute an objection.

84 See Gaitskill: "I love her-I love her dearly-because I'm her mother and I can't help it. But I don't like her" ("Heaven," 202). Compare Velleman: "It is easy enough to love someone whom one cannot stand to be with" ("Love as a Moral Emotion," 361). Another common and related case is that of young siblings: we sometimes say that they love each other, even though they "cannot stand one another." Here is my brief interpretation of this assertion by way of an analogy. I really like Vertigo. Nonetheless, if you were to play this film on my television every morning for a dozen years, I might at some point begin to say that I cannot stand it. In other words, overexposure to things that we like makes us inclined to say that we dislike them; and in some real ways we do. But it is very unclear what to conclude. Lost Cause is a less noisy case that better expresses the essence of the disagreement. 
My claim is that liking the objects of our devotion is a critical part of finding our interactions with them to be reliable sources of meaning in life. I cannot defend this view except by employing imaginative exercises. So I ask the reader to imagine that her life is filled with devotion that renders vulnerable but does not express liking. In order to do this, she might begin by imaginatively inhabiting Jill's position, and generalizing it across the space of her intimate relations. ${ }^{85}$ She might then attempt to inhabit the unfortunately all-too-common experience of vulnerable devotion to a career that she does not like. And so on. Writ large upon the canvas of a life, this psychological condition seems to me a case study in existential malaise.

I have one more argument for the liking component, which is error-theoretic, i.e., a diagnosis of why we may be inclined to mistakenly reject it. The diagnosis is that we think of Jill's vulnerable devotion as especially praiseworthy. Our commitment to its moral worth infects our judgments about whether Jill loves Beelzebub - which is unsurprising, given that "love" often functions as a kind of moral honorific. Refusing to admit Jill into the class of lovers can seem cold. It feels like a refusal to bestow moral approval where it is due. This natural thought should be resisted, though. There are many praiseworthy orientations of mind that moral psychology should distinguish.

The availability of this error theory supports my skepticism about largely unsupported intuitions that sever loving from liking. And we should recall that cases like Jill's are relatively unusual, and hard to describe and interpret. Whatever we think about whether Jill should count as a lover in some sense, I take myself to have provided reasons for thinking that she is not a lover in the sense of interest here, in which love is the condition most robustly connected to the experience of meaning.

\section{CONCLUDING REMARKS}

In presenting the tripartite theory, I suggested that it could explain and perhaps

85 For a grave comparison, consider Andrew Solomon's profile of Peter Lanza, the father of the Sandy Hook killer. Here is how the piece ("The Reckoning") concludes:

I wondered how Peter would feel if he could see his son again. "Quite honestly, I think that I wouldn't recognize the person I saw," he said. "All I could picture is there'd be nothing there, there'd be nothing. Almost like, 'Who are you, stranger?" Peter declared that he wished Adam had never been born, that there could be no remembering who he was outside of who he became. "That didn't come right away. That's not a natural thing, when you're thinking about your kid. But, God, there's no question. There can only be one conclusion, when you finally get there. That's fairly recent, too, but that's totally where I am." 
dissolve puzzles about the connections between love and rational agency. These puzzles concern perennial topics of interest in philosophy, literature, and the arts. Is love an emotion? Is it under our control? Are we responsible for it? Is it governed by reason, and subject to evaluation? Are its demands antagonistic or complementary to the demands of morality?

These questions are enduring objects of fascination partly because we have never agreed about what love is. In providing a detailed account of love as a psychological kind, the tripartite theory furnishes us with new materials for answering them. Even opponents of the theory may find it useful for identifying the at times murky fault lines dividing opposing conceptualizations of this elusive psychological condition.

To conclude, I offer a pregnant observation about one of these themes, which has been anticipated at various points above.

Puzzling intuitions about control and responsibility animate thinking about love in everyday as well as philosophical discourse. Compare the following representatively incompatible passages from Roger Scruton and Robert Solomon:

Erotic love, like the love of children, is compelled by the embodiment of its object.... We are subjected by erotic love.... Our freedom suffers the impact of an external necessity. Erotic love is experienced, not as a decision, but as a destiny. ${ }^{86}$

Love is a decision. A decision to love, and a decision about whom to love, and how, and when, and why. Romantic love is an emotion of choice. ${ }^{87}$

We commonly presuppose something like Scruton's view that love-especially erotic love-is akin to a compulsion, or even a sickness that overwhelms our agency. ${ }^{88}$ And this leads us to make ambitious assumptions about responsibility and justification, for example concerning the inaptness of blame. ${ }^{89}$ Yet we also

86 Scruton, Sexual Desire, 233.

87 Solomon, Love, 212.

88 Compare Cervantes: "Perhaps you consider me a man whose power of reasoning is weak and, even worse, one who has no judgment at all. It would not be surprising if that were the case, because it is evident to me that in my imagination the power of my afflictions is so intense and contributes so much to my ruination that I am powerless to prevent it and I become like a stone" (Don Quixote, 234). And see how Wilcox, "Love's Coming," expresses the presupposition: "She had looked for his coming as warriors come,/with the clash of arms and the bugle's call; /but he came instead with a stealthy tread,/which she did not hear at all."

89 See Lewis: "When lovers say of some act that we might blame, 'Love made us do it,' notice the tone. A man saying, 'I did it because I was frightened,' or 'I did it because I was angry,' speaks quite differently. He is putting forward an excuse for what he feels to require ex- 
find ourselves deeply uncomfortable with these intuitions. Upon reflection, all does not seem to be fair, permitted, or excusable even in "matters of the heart." 90 The tripartite theory allows us to make a simple conjecture about these deep perplexities. Our intuitions are muddled because love is a composite psychological condition, whose component parts are very differently susceptible to control, and very differently amenable to normative assessment.

Even the most ambitiously rationalistic philosopher will acknowledge that our fundamental likes and affinities are hard to manipulate directly. Something similar might be said about the intentional manipulation of our vulnerabilities, once we have come to have them. Whereas we may choose to devote ourselves to a child, a cat, or a project in a way that resembles how we may choose to raise an arm. These claims about control shape our intuitions about responsibility for love, and assessment of it, in predictably interesting ways.

Much more needs to be said to vindicate the importance of this final set of observations. I hope that this essay has paved the way by presenting a plausible and distinctive conception of love that illuminates to some degree the connection between love and meaning. ${ }^{91}$

\author{
The University of Sydney \\ sam.shpall@sydney.edu.au
}

cusing. But the lovers are seldom doing quite that. Notice how tremulously, almost how devoutly, they say the word love, not so much pleading an 'extenuating circumstance' as appealing to an authority" (The Four Loves, 136).

Compare Korsgaard: "I am using the term 'grounds' here not to avoid but rather to emphasize the obscurity of the because in love, which seems to fall somewhere in between the because of practical reason and the because of causality. The grounds of love do seem to have something in common with practical reasons ... they are unlike mere causes, and like practical reasons, in that they can (sometimes) be right or wrong, or at least better and worse.... Yet the grounds of love do not quite seem to be practical reasons, and indeed seem to operate more like causes. To the extent that love is a passion, we do not decide to love on the basis of its grounds, for we do not decide to love at all.... For all of these reasons, the notion we are dealing with is an obscure one, in need of more philosophical attention" (“The General Point of View," 8).

91 For especially helpful comments and encouragement, I would like to thank Zed Adams, Richard Arneson, Julia Borcherding, David Brink, Gabriel Citron, Stephen Darwall, Kory DeClark, Kenny Easwaran, Nate Gadd, Daniel Greco, Daniel Harris, Bennett Helm, Agnieszka Jaworska, Yao Lin, Dustin Locke, Errol Lord, Rachel McKinney, Eliot Michaelson, Shyam Nair, Aaron Norby, Alejandro Pérez-Carballo, David Plunkett, Sara Protasi, Daniel Putnam, Jacob Ross, Samuel Rickless, Jeffrey Seidman, Mark Schroeder, Gary Watson, Caroline West, Gideon Yaffe, Yuan Yuan, and an anonymous reviewer for JESP. 


\section{REFERENCES}

Abramson, Kate, and Adam Leite. "Love as a Reactive Emotion." The Philosophical Quarterly 61, no. 245 (October 2011): 673-99.

Aristotle. Nicomachean Ethics. Translated by Terence Irwin. Indianapolis: Hackett Publishing, 1999.

Austen, Jane. Pride and Prejudice. 1813. Mineola, NY: Dover Publications, 1995.

Badhwar, Neera. "Love." In The Oxford Handbook of Practical Ethics, edited by Hugh LaFollette, 42-69. Oxford: Oxford University Press, 2005.

Bagley, Benjamin. "Loving Someone in Particular." Ethics 125, no. 2 (January 2015): 477-507.

Berridge, Kent C. "Wanting and Liking: Observations from the Neuroscience and Psychology Laboratory." Inquiry 52, no. 4 (2009): 378-98.

Bratman, Michael. Intention, Plans, and Practical Reason. Cambridge, MA: Harvard University Press, 1987.

Brink, David. "Eudaimonism, Love and Friendship, and Political Community." Social Philosophy and Policy 16, no. 1 (Winter 1999): 252-89.

Brogaard, Berit. On Romantic Love: Simple Truths about a Complex Emotion. Oxford: Oxford University Press, 2015.

Cervantes, Miguel de. Don Quixote. 1615. Translated by Edith Grossman. New York: Harper Collins, 2003.

Charles, Dan. "A Crime of Passion: When the Love of Yogurt Burned Too Bright." National Public Radio, July 13, 2015.

Cocking, Dean, and Jeanette Kennett. "Friendship and Moral Danger." Journal of Philosophy 97, no. 5 (May 2000): 278-96.

—. "Friendship and the Self." Ethics 108, no. 3 (April 1998): 502-27.

de Sousa, Ronald. Love: A Very Short Introduction. Oxford: Oxford University Press, 2015.

Eaton, A.W., ed. Talk to Her: Philosophers on Film. Abingdon, UK: Routledge, 2008.

Ebels-Duggan, Kyla. "Against Beneficence: A Normative Account of Love." Ethics 119, no. 1 (October 2008): 142-70.

Ferracioli, Luara. "The State's Duty to Ensure Children Are Loved." Journal of Ethics and Social Philosophy 8, no. 2 (September 2014): 1-19.

Foot, Philippa. Natural Goodness. Oxford: Oxford University Press, 2001.

Frankfurt, Harry. "Autonomy, Necessity, and Love." In Necessity, Volition, and Love, 129-41. Cambridge: Cambridge University Press, 1999.

. The Importance of What We Care About. Cambridge: Cambridge University Press, 1988. 
. "On Caring." In Necessity, Volition, and Love, 155-80. Cambridge: Cambridge University Press, 1999.

- The Reasons of Love. Princeton: Princeton University Press, 2004.

Fricker, Miranda. Epistemic Injustice. New York: Oxford University Press, 2007.

Fromm, Erich. The Art of Loving. London: Unwin Books, 1971.

Frost, Kim. "On the Very Idea of Direction of Fit." Philosophical Review 123, no. 4 (2014): 429-84.

Gaitskill, Mary. "Heaven." In Bad Behavior: Stories, 177. New York: Simon and Schuster, 1988.

García Márquez, Gabriel. Love in the Time of Cholera. Translated by Edith Grossman. New York: Knopf, 1987.

Goldie, Peter. "Love for a Reason." Emotion Review 2, no. 1 (2010): 61-67.

Griffiths, Paul. "Current Emotion Research in Philosophy." Emotion Review 5, no. 2 (2013): 215-22.

Harman, Gilbert. Change in View. Cambridge, MA: MIT Press, 1986.

- . "Practical Reasoning." In Review of Metaphysics, edited by Alfred R. Mele, 431-63. Oxford: Oxford University Press, 1976.

Helm, Bennett. Emotional Reason: Deliberation, Motivation, and the Nature of Value. Cambridge: Cambridge University Press, 2000.

- "Love." Stanford Encyclopedia of Philosophy (Fall 2017). https://plato. stanford.edu/archives/fall2017/entries/love.

. Love, Friendship, and the Self. Oxford: Oxford University Press, 2010.

Jenkins, Carrie. "Modal Monogamy." Ergo 2, no. 8 (2015).

.What Love Is: And What It Could Be. New York: Basic Books, 2017.

Jollimore, Troy. Love's Vision. Princeton: Princeton University Press, 2011.

Kant, Immanuel. Grounding for the Metaphysics of Morals. 1785. Translated by James W. Ellington. Indianapolis: Hackett Publishing Company, 1993.

- The Metaphysics of Morals. 1797. Edited by Mary Gregor. Cambridge: Cambridge University Press, 1996.

Kennett, Jeanette. “True and Proper Selves: Velleman on Love." Ethics 118, no. 2 (2008): 213-27.

Kenny, Anthony. Action, Emotion, and Will. Abingdon, uk: Routledge, 1963.

Kolodny, Niko. "Love as Valuing a Relationship." Philosophical Review 112, no. 2 (2003): 135-89.

Korsgaard, Christine. "The General Point of View: Love and Moral Approval in Hume's Ethics." Hume Studies 25, nos. 1 and 2 (1999): 3-41.

Langton, Rae. "Duty and Desolation." Philosophy 67, no. 262 (1992): 481-505. Lear, Jonathan. Love and Its Place in Nature: A Philosophical Interpretation of Freudian Psychoanalysis. New Haven, Ст: Yale University Press, 1990. 
Lewis, C. S. The Four Loves. 1960. New York: HarperCollins, 2012.

Liao, Matthew. "The Right of Children to Be Loved." Journal of Political Philosophy 14, no. 4 (December 2006): 420-40.

- The Right to Be Loved. Oxford: Oxford University Press, 2015.

Machado, Carmen Maria. "Mothers." In Her Body and Other Parties, 45-64. Minneapolis: Graywolf Press, 2017.

Mill, John Stuart. Autobiography of John Stuart Mill. 1873. New York: Columbia University Press, 1969.

- Utilitarianism. 1861. Edited by George Sher. Indianapolis: Hackett Publishing, 2001.

Millgram, Elijah. "Kantian Crystallization." Ethics 114, no. 3 (April 2004): 511-13. Murdoch, Iris. The Black Prince. London: Penguin Classics, 2003.

Naar, Hichem. "A Dispositional Theory of Love." Pacific Philosophical Quarterly 94, no. 3 (September 2013): 342-57.

Nehamas, Alexander. "The Good of Friendship." Proceedings of the Aristotelian Society 110 (2010): 267-94.

-. On Friendship. New York: Basic Books, 2016.

- Only a Promise of Happiness. Princeton: Princeton University Press, 2007.

Nelson, Maggie. Bluets. Seattle: Wave Books, 2009.

Nozick, Robert. "Love's Bond." In The Examined Life: Philosophical Meditations, 68-86. New York: Simon and Schuster, 1989.

Nussbaum, Martha. Upheavals of Thought: The Intelligence of Emotions. Cambridge: Cambridge University Press, 2001.

Shpall, Sam. "Love's Objects." In Love, Reason, and Morality, edited by Katrien Schaubroeck and Esther Engels Kroeker, 57-74. New York: Routledge, 2017.

- "The Men of Talk to Her." Film and Philosophy 17 (2013): 96-112.

Plato. Symposium. In Plato: Complete Works, edited by John M. Cooper, 457-505. Indianapolis: Hackett Publishing, 1997.

Proust, Marcel. Remembrance of Things Past. 1913-1927. Translated by C. K. Scott Moncrieff, Terence Kilmartin, and Andreas Mayer. 3 vols. New York: Random House, 1981.

Raz, Simcha. A Tzaddik in Our Time: The Life of Rabbi Aryeh Levin. Translated by Charles Wengrov. Jerusalem: Feldheim Publishers, 1976.

Roberts, Robert C. Emotions: An Essay in Aid of Moral Psychology. Cambridge: Cambridge University Press, 2003.

Rorty, Amelie. "The Burdens of Love." Journal of Ethics 20, no. 4 (December 2016): 341-54. 
Safina, Carl. Beyond Words: What Animals Think and Feel. New York: Henry Holt and Company, 2015.

Scruton, Roger. Sexual Desire: A Philosophical Investigation. London: Weidenfeld and Nicolson, 1986.

Setiya, Kieran. "Cognitivism about Instrumental Reason." Ethics 117, no. 4 (July 2007): 649-73.

- "Love and the Value of a Life." Philosophical Review 123, no. 3 (July 2014): 251-80.

- “The Midlife Crisis." Philosophers' Imprint 14, no. 31 (November 2014): $1-18$.

Singer, Irving. "From The Nature of Love." In The Philosophy of Erotic Love, edited by Robert C. Solomon and Kathleen M. Higgins, 259-78. Lawrence: Kansas University Press, 1991.

Sinhababu, Neil. "The Humean Theory of Motivation Reformulated and Defended." Philosophical Review 118, no. 4 (October 2009): 465-500.

Smith, Michael. The Moral Problem. Hoboken, NJ: Blackwell Publishing, 1994.

Smuts, Aaron. "Normative Reasons for Love, Parts I and II." Philosophy Compass 9, no. 8 (August 2014): 507-26.

Soble, Alan. "Concerning Self-Love: Analytic Problems in Frankfurt's Account of Love." Essays in Philosophy 12, no. 1 (January 2011): 55-67.

. The Philosophy of Sex and Love. 2 nd ed. St. Paul, MN: Paragon House, 2008.

Solomon, Andrew. “The Reckoning." New Yorker. March 17, 2014. https://www. newyorker.com/magazine/2014/03/17/the-reckoning.

Solomon, Robert. About Love: Reinventing Romance for Our Times. New York: Simon and Schuster, 1988.

- Love: Emotion, Myth, and Metaphor. Amherst, NY: Prometheus Books, 1990.

Sternberg, Robert. “The Triangular Theory of Love." Psychological Review 93, no. 2 (1986): 119-35.

Taylor, Gabriele. "Love." Proceedings of the Aristotelian Society 76 (1976): 147-64. Teresa of Ávila. The Complete Works of Saint Teresa of Jesus. Vol. 2. Translated and edited by E. Allison Peers. London: Sheed and Ward, 1975.

Velleman, J. David. "Beyond Price." Ethics 118, no. 2 (January 2008): 191-212.

—. "Love as a Moral Emotion." Ethics 109, no. 2 (January 1999): 338-74.

- Practical Reflection. Princeton: Princeton University Press, 1989.

Wilcox, Ella Wheeler. "Love's Coming." In Poetical Works of Ella Wheeler Wilcox. Edinburgh: W. P. Nimmo, Hay, and Mitchell, 1917. 
Williams, Bernard. "Persons, Character and Morality." In Moral Luck, 1-19. Cambridge: Cambridge University Press, 1981.

Wolf, Susan. Meaning in Life and Why It Matters. Princeton: Princeton University Press, 2010.

. The Variety of Values: Essays on Morality, Meaning, and Love. Oxford: Oxford University Press, 2015.

Wonderly, Monique. "Love and Attachment." American Philosophical Quarterly 54, no. 3 (July 2017): 235-50. 